\title{
New record of four sand fly species (Diptera, Psychodidae) in Rondônia State, Western Amazon, Brazil
}

\author{
A. M. Pereira Júnior ${ }^{a, b, c}$ (D), F. Resadore (D), A. N. Rodrigues $^{a, b}$ (D), G. E. M. Ferreira ${ }^{c, d}$ (D), \\ G. R. Julião ${ }^{b, c}$ (D) and J. F. Medeiros $* b, c$ (D)
}

aPrograma de Pós-graduação em Biologia Experimental, Fundação Universidade Federal de Rondônia - UNIR, Rod. BR 364, Km 9,5, CEP 76801-059, Porto Velho, RO, Brasil

bLaboratório de Entomologia, Fundação Oswaldo Cruz - Fiocruz Rondônia, Rua da Beira, 7671, CEP 76812-245, Porto Velho, RO, Brasil

'Instituto Nacional de Epidemiologia da Amazônia Ocidental - INCT-EpiAMO, Rua da Beira, 7671, CEP 76812-245, Porto Velho, RO, Brasil

'Laboratório de Epidemiologia Genética, Fundação Oswaldo Cruz - Fiocruz Rondônia, Rua da Beira, 7671, CEP 76812-245, Porto Velho, RO, Brasil

*e-mail: jmedeiro@gmail.com

Received: December 12, 2018 - Accepted: February 14, 2019 - Distributed: February 28, 2020

(With 2 figures)

Sand flies are insects of medical importance that are present in high diversity in the Neotropical region. In Brazil, approximately 280 species have been recorded (Galati, 2018) and 13 of these species are proven vectors of Leishmania spp. (Rangel et al., 2018). Prior to this study, 131 species had been recorded in Rondônia State (Galati, 2018).

This study presents new records of four sand fly species found in Rondônia State. These records are of male specimens collected between 2016 and 2017 using HP light traps. Collections were made in three protected areas that are characterized by dense ombrophylous forest: 1- Jamari National Forest, Itapuã do Oeste municipality, 2- Jaru Biological Reserve, Vale do Anari and Ji-Paraná municipalities, 3- Guajará-Mirim State Park, Nova Mamoré municipality. Collections were also made in forest fragments near dwellings in periurban areas located in the municipalities of Cacoal and Monte Negro (Figure 1).

A total of 9,415 sand flies of the genera Bichromomyia, Brumptomyia, Evandromyia, Lutzomyia, Martinsmyia, Micropygomyia, Migonemyia, Nyssomyia, Pintomyia, Pressatia, Psathyromyia, Psychodopygus, Sciopemyia, Trichophoromyia, Trichopygomyia and Viannamyia were slide-mounted and species identification was performed using the identification keys proposed by Galati (2018). The new records were deposited in the Entomology Laboratory of Fiocruz Rondônia and include the following species:

Brumptomyia mesai Sherlock, 1962 (1 Ĵ, Figures 2A, B), collected in Guajará-Mirim State Park, Nova Mamoré municipality, in a forest environment on the Cachoeira track (643' $\left.10^{\prime \prime} \mathrm{W}, 10^{\circ} 18^{\prime} 57^{\prime} \mathrm{S}\right)$. This is the first record of $B$. mesai in an ombrophylous forest in the North Region of Brazil. This species was previously discovered in an armadillo's hole and in a forest environment in the Colombian Amazon (Sherlock, 1962; Bejarano et al., 2007). This species is distributed among the Central American countries of Belize, Honduras, Mexico, and in the Trans-Andean region of the Chocó, Sucre and Santander Departments of
Colombia (Sherlock, 1962; Bejarano et al., 2007; Vivero Gomez et al., 2011; Galati, 2018). In Brazil, B. mesai has been recorded in Mato Grosso do Sul, Paraná, São Paulo and now in Rondônia State (Galati, 2018).

Psathyromyia elizabethdorvalae Brilhante, Sábio \& Galati, 2017 ( 1 今 , Figure 2C) was found in a small ombrophylous forest fragment $\left(63^{\circ} 19^{\prime} 52.5^{\prime \prime} \mathrm{W}, 10^{\circ} 15^{\prime} 37.8^{\prime} \mathrm{S}\right)$ in Monte Negro municipality. Records of this species have been made in other regions of the Amazon basin, primarily in forest and peridomicile environments in Xapuri municipality, Acre State (Brilhante et al., 2017).

Nyssomyia delsionatali Galati \& Galvis, 2012 $\left(2{ }^{\lambda}\right.$, Figures $\left.2 \mathrm{D}, \mathrm{E}\right)$ was found in a peridomicile environment in Cacoal municipality (61 $\left.22^{\circ} 05^{\prime} \mathrm{W}, 11^{\circ} 29^{\prime} 11^{\prime} \mathrm{S}\right)$, and in dense ombrophylous forest on the Jaru Biological Reserve (61³9'48'W, 9³8'50’'S). This species was first recorded in Mato Grosso State, and was subsequently recorded in Espírito Santo (FIOCRUZ, 2019); both findings were made in forest environments. Rondonia is the third state to record the presence of $N$. delsionatali (Galati, 2018).

Trichopygomyia wagleyi (Causey \& Damasceno, 1945) ( $2 \hat{\delta}$, Figure 2F) has been recorded in Amazonas State, primarily in forest fragments (Pereira Júnior et al., 2015). In a recent survey of the road that connects Amazonas and Rondônia states, this species was found in a forest edge near peridomiciles (Julião et al., 2019) and in upland forest areas near small farms in a municipality along the middle Solimões River (Pereira Júnior et al., 2015). This species has also been recorded in tropical rain forests in Venezuela, Colombia and Bolivia (Galati, 2018). In our study, this species was found in the National Forest of Jamari (6254'48.30'”, 9¹5'36.10”S), a conservation unit characterized by dense ombrophylous forest.

This study increases the number of species recorded in Rondônia to 135 , an increase of nearly 4\%, and it updates the number of species from genera found in Rondonia to: Brumptomyia (6), Nyssomyia (9), Psathyromyia (31) and Trichopygomyia (6). 


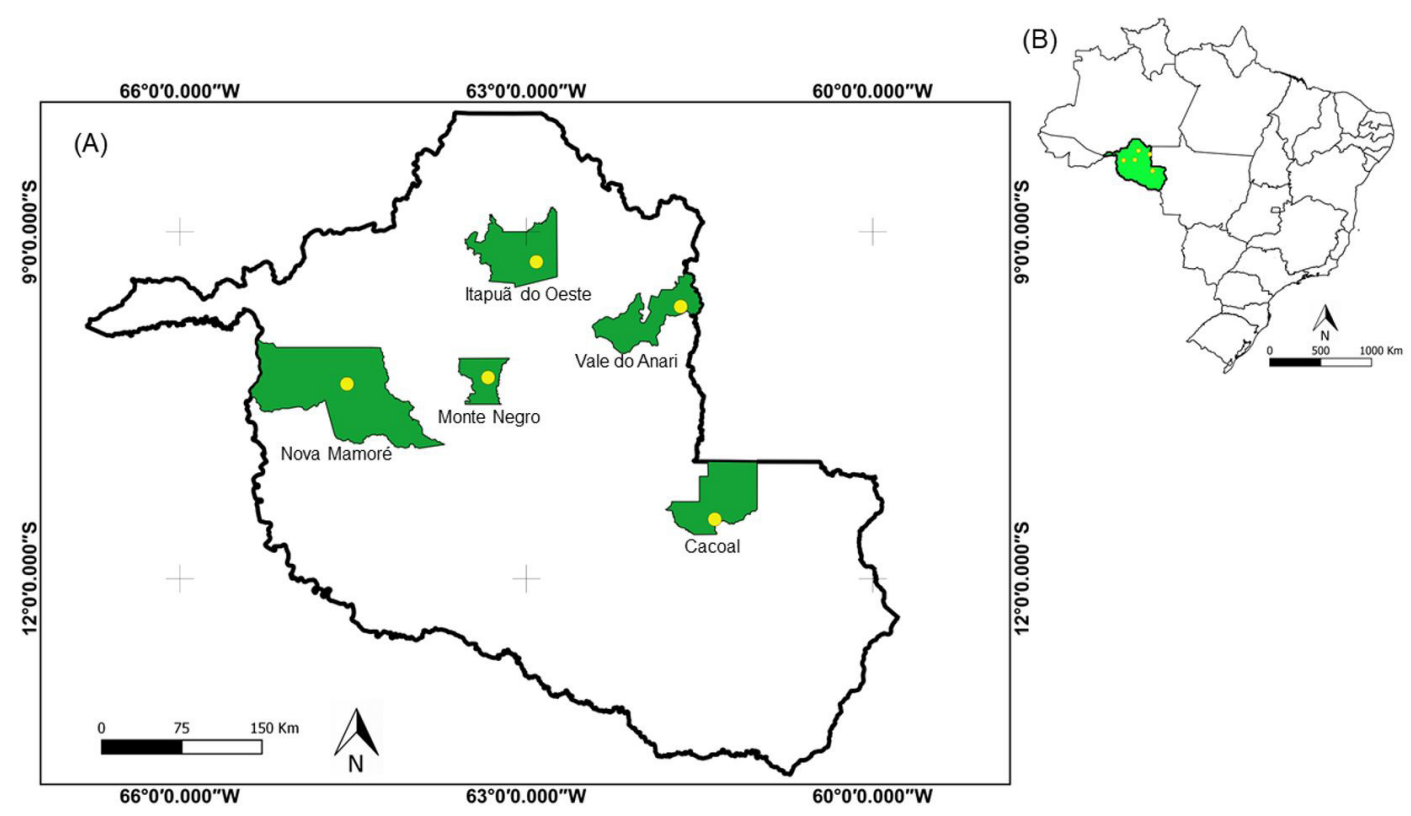

Figure 1. Collection points of the new sand fly records to Rondônia State, Brazil. In the map (A) are indicated with the green color the municipalities and with yellow circles are highlighted the collection points of sand flies. In the map (B) is highlighted the Rondônia State territory in Brazil.
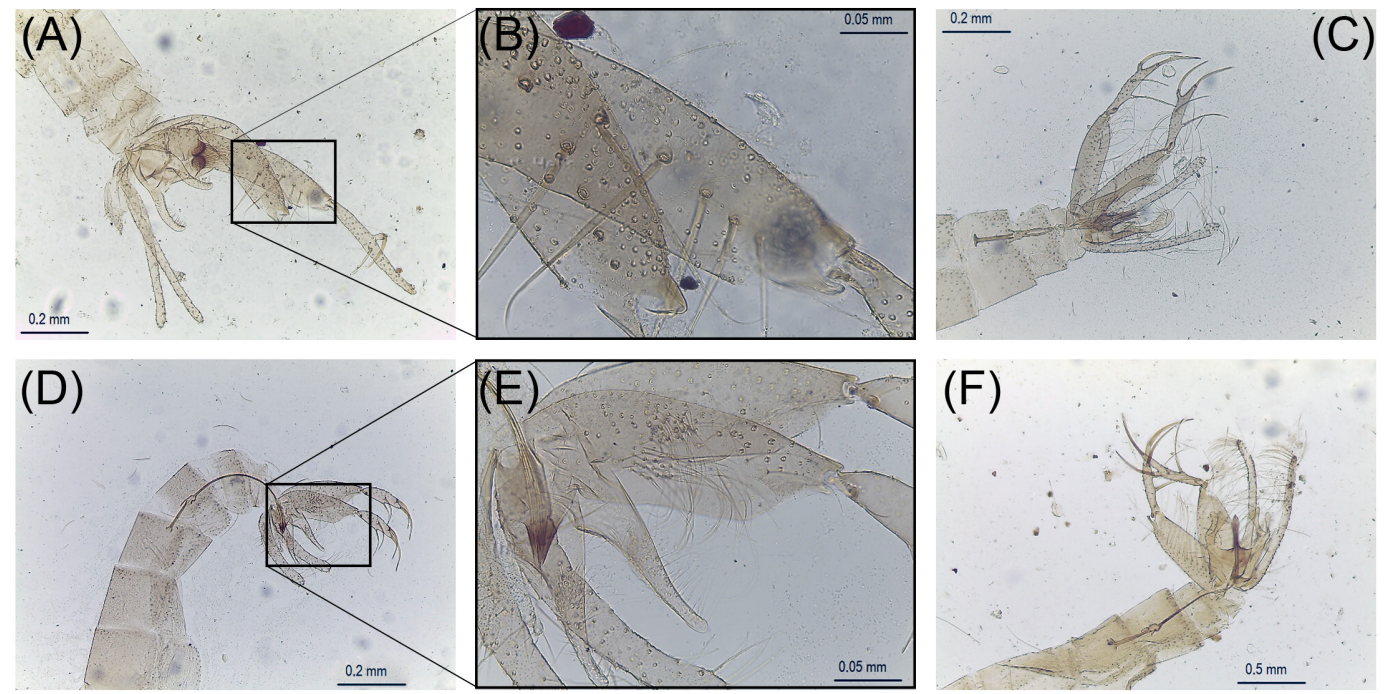

Figure 2. Male genitalia from the new sand fly records for Rondônia State. The identification of Brumptomyia mesai is based on its gonocoxite which bears a basal tuft of setae (A), and five to six setae in the apex region of this structure (B). Psathyromyia elizabethdorvalae is characterized by epandrial lobes 1.2 times longer than the gonocoxite; parameres simple with dorsal margin presenting slight curvature preceding apex, edeagal ducts length 1.9 times longer than genital pump and gonostyle with four well developed spines (C). Nyssomyia delsionatali is differentiated by parameres with apex slightly curved (D) and gonocoxite bearing a group of less than 25 setae (E). Trichopygomyia wagleyi is identified by a paramere format in which the dorsal part is more dilated than the base $(\mathrm{F})$.

\section{References}

BeJARANo, E.E., CASTRO, M., PÉREZ-Doria, A., HERNÁNDEZ-OVIEDO, E., VÉLEZ, A. and VÉLEZ, I.D., 2007. Primer informe de Lutzomyia França en el departamento de Guainía, Amazonia Colombiana, y de Brumptomyia mesai Sherlock (Diptera: Psychodidae) en el Litoral Caribe Colombiano. Neotropical Entomology, vol. 36, no. 6, pp. 990993. http://dx.doi.org/10.1590/S1519-566X2007000600027. PMid: 18246280. 
BRILHANTE, A.F., SÁBIO, P.B. and GALATI, E.A.B., 2017. A new species of Sand Fly, Psathyromyia elizabethdorvalae sp. n. (Diptera: Psychodidae: Phlebotominae), from Brazil. Journal of Medical Entomology, vol. 54, no. 1, pp. 76-81. http://dx.doi. org/10.1093/jme/tjw150. PMid:28082633.

FUNDAÇÃO OSWALDO CRUZ - FIOCRUZ, 2019 [viewed 25 January 2019]. Coleção de Flebotomíneos: COLFLEB [online]. Available from: http://www.splink.org.br/index?lang=pt

GALATI, E.A.B., 2018. Phlebotominae (Diptera, Psychodidae): classification, morphology and terminology of adults and identification of american taxa. In: E.F. RANGEL and J.J. SHAW, eds. Brazilian sand flies: biology, taxonomy, medical importance and control. Gewerbestrasse: Springer, pp. 9-212.

JULIÃO, G.R., NOVO, S.P.C., RÍOS-VELÁSQUEZ, C.M., DESMOULIĖRE, S.J.M., LUZ, S.L.B. and PESSOA, F.A.C., 2019. Sand fly fauna associated with dwellings and forest habitats along the BR-319 highway, Amazonas, Brazil. Journal of Medical Entomology, vol. 56, no. 2, pp. 540-546. http://dx.doi.org/10.1093/ jme/tjy179. PMid:30304536.

PEREIRA JÚNIOR, A.M., TELES, C.B.G., SANTOS, A.P.A., RODRIGUES, M.S., MARIALVA, E.F., PESSOA, F.A.C. and
MEDEIROS, J.F., 2015. Ecological aspects and molecular detection of Leishmania DNA Ross (Kinetoplastida: Trypanosomatidae) in phlebotomine sandflies (Diptera: Psychodidae) in terra firme and várzea environments in the Middle Solimões Region, Amazonas State, Brazil. Parasites \& Vectors, vol. 8, no. 1, pp. 180. http:// dx.doi.org/10.1186/s13071-015-0789-2. PMid:25889808.

RANGEL, E.F., LAINSON, R., CARVALHO, B.M., COSTA, S.M. and SHAW, J.J. 2018. Sand fly Vectors of American Cutaneous Leishmaniasis in Brazil. In: E.F. RANGEL and J.J. SHAW, eds. Brazilian sand flies: biology, taxonomy, medical importance and control. Gewerbestrasse: Springer, pp. 341-380. http://dx.doi. org/10.1007/978-3-319-75544-1_7.

SHERLOCK, I.A., 1962. Sôbre alguns Phlebotomus e Brumptomyia da Colômbia (Diptera, Psychodidae). Memórias do Instituto Oswaldo Cruz, vol. 60, no. 3, pp. 321-336. http:// dx.doi.org/10.1590/S0074-02761962000300004.

VIVERO GOMEZ, R.F., MUSKUS LOPES, C.E. and TORRES GUTIERREZ, C., 2011 [viewed 25 January 2019]. Fauna de flebotomíneos (Diptera: Psychodidae) en Acandí (Chocó). Acta Biologica Colombiana [online], vol. 16, no. 1, pp. 209-218. Available from: https://revistas.unal.edu.co/index.php/actabiol/ article/view/15922/28149 